\title{
PENGUKURAN DAN ANALISIS KEBISINGAN PERMUKIMAN TEPI REL KERETA LISTRIK
}

\author{
Erna Kusuma Wati \\ Program Studi Teknik Fisika, Universitas Nasional \\ ernakusuma.w@gmail.com
}

Submitted December 14, 2019; Revised March 20, 2020; Accepted March 22, 2020

\begin{abstract}
Abstrak
Penelitian mengenai sebaran tingkat kebisingan di permukiman yang berada di dekat jalur rel KRL (kereta Rel Listrik), dilakukan di permukiman Tebet Timur Dalam, DKI Jakarta, guna mengetahui Nilai Ambang Batas (NAB) kebisingan di permukiman tersebut sudah sesuai dengan standard atau belum. Jika belum maka perlu dilakukan rekomendasi untuk mengurangi kebisingan tersebut. Waktu pengambilan data adalah selama dua minggu dengan menggunakan metode grid dalam menentukan titik koordinat. Pengambilan data tingkat kebisingan pada tiap titik dilakukan dalam kurun waktu 24 Jam sebanyak enam waktu. Pemetaan sebaran kebisingan menggunakan aplikasi Surfer dengan metode kriging dan data berupa titik koordinat dan nilai hasil pengukuran. Titik koordinat didapatkan menggunakan aplikasi android bernama UTM Geo Map. Hasil pengukuran menunjukkan tingkat kebisingan LSM tertinggi pada jarak 20 meter pada Gang C sebesar 80,5 dBA, dan data hasil LSM terendah pada jarak 80 meter dari sumber kebisingan pada Gang B sebesar 54,2 dBA. Jarak aman yang direkomendasikan untuk mendirikan permukiman adalah diatas 80 meter karena sesuai dengan NAB. rekomendasi lainnya guna meredam kebisingan yaitu dengan memberi penghalang berupa pohon atau tembok beton yang membatasi pinggir rel kereta pada jarak minimal sejauh lima meter dengan daerah permukiman warga.
\end{abstract}

Kata Kunci : kebisingan, kereta, surfer

\begin{abstract}
Research on the distribution of noise level in settlement near the KRL (Electric Train) railway is conducted in Tebet Timur Dalam settlement, DKI Jakarta to determine if the Threshold Value (NAB) of noise in the settlement is by standards or not. If not, then a recommendation is needed to reduce the noise. The data are collected in two weeks, during which the grid method is used to determine the coordinates. Noise level data collection at each point is carried out within 24 hours of six time periods. The mapping of the distribution of noise is conducted using the Surfer application with kriging method, with data in the form of coordinates and measurement results. The coordinates are obtained using an android application called UTM Geo Map. The measurement results show the highest LSM noise level is at a distance of 20 meters in Gang C of 80.5 dBA, while the lowest LSM data result is at a distance of 80 meters from the noise source at Gang B of $54.2 \mathrm{dBA}$ The recommended safe distance to establish a settlement is above 80 meters because it is according to the $N A B$. Another recommendation to reduce noise is to provide a barrier in the form of trees or concrete walls that limit the edge of the railway at a minimum distance as far as five meters from the residential area.
\end{abstract}

Keywords: noise, train, surfer

\section{PENDAHULUAN}

Kereta Rel Listrik (KRL) merupakan jalur tarnsportasi di Jakarta yang memiliki jalur dan jam operasional tinggi, tidak heran apabila jalur perlintasannya sangat padat, setiap lima belas menit KRL melintas. Jalur lalu lintas kereta memiliki tingkat kebisingan mencapai 100 dBA [1] sehingga dapat merusak telinga. 
Resiko yang diakibatkan oleh kebisingan/pencemaran udara lalu lintas KRL selain mempengaruhi kualitas udara [2] juga dapat berdampak bagi kesehatan pada orang disekitarnya. Contohnya, perubahan tekanan darah bagi penduduk yang diakibatkan oleh kebisingan beserta getaran karena tinggal di permukiman dekat dengan jalur rel kereta [3]. Sehingga perlu diperhatikan Nilai Ambang Batas (NAB) yang diizinkan yakni 55 dBA [4], untuk mendirikan suatu bangunan agar terhindar dari segala resiko tersebut.

Permukiman di daerah Tebet Timur dalam merupakan padat penduduk, yang berada di jalur rel KR. Perlu adanya pengukuran kebisingan pada tiap-tiap titik di permukiman tersebut untuk mengetahui sebaran tingkat kebisingannya, dan jika melewati (NAB) maka perlu dilakukan rekomendasi untuk mengurangi kebisingan tersebut.

\section{METODE PENELITIAN}

Penelitian dilakukan di daerah permukiman Tebet Timur, Jakarta Selatan, DKI Jakarta, pada jam operasional Kereta Rel Listrik (KRL) yaitu dari jam 05.50 sampai 23.45 (Red Line) jurusan Jakarta Kota-Bogor.

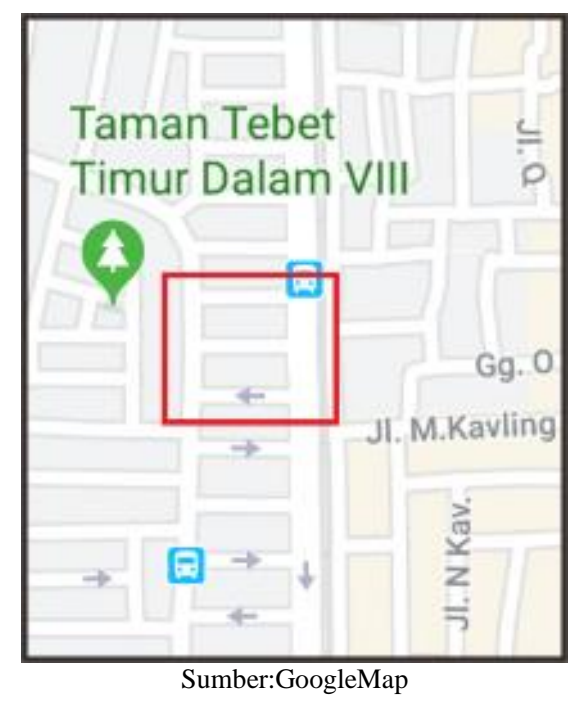

Gambar 1. Lokasi Penelitian
Penentuan titik-titik pengukuran menggunakan metode grid. Hal ini untuk mencari nilai sebaran data kebisingan dan memudahkan untuk mengetahui seberapa jauh jarak aman dari sumber kebisingan (rel kereta). Pola sebaran kebisingan diperoleh dengan pendekatan kaidah kontur, yaitu membuat garis-garis koordinat $\mathrm{x}, \mathrm{y}$, dan $\mathrm{z}$ yang menghubungkan tingkat kebisingan yang berbeda dengan sumber yang sama.

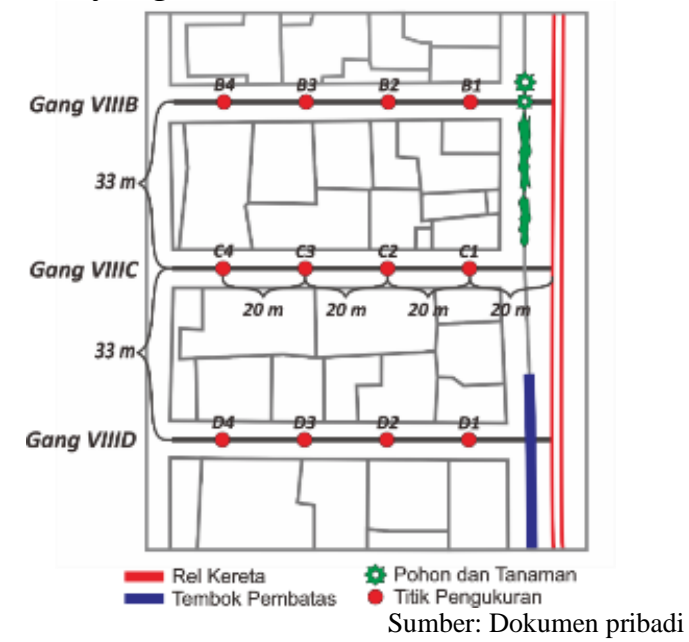

Gambar 2. Titik Pengambilan Data

Jarak titik pengukuran satu dan yang lainnya ditentukan sejauh 20 meter. Jarak 20 meter digunakan untuk mempermudah mengetahui jarak aman tingkat kebisingan dari sumber kebisingan. kebisingan di ukur dengan Sound Level Meter (SLM) pada satuan decibel (dB) dengan posisi ketinggian sejauh $120 \pm 10 \mathrm{~cm}$ dari permukaan tanah [5].

Metode Pengambilan data tingkat kebisingan diambil selama \pm 60 menit yang mewakili beberapa jam. Pengukuran pada siang hari dilakukan minimal 4 waktu, dan pada malam hari minimal 3 waktu [4]. Berdasarkan jam operasi KRL dari jam 05.00-24.00 maka pada pengukuran malam hanya dilakukan 2 pengukuran

a) L1 data pengukuran di jam 06.00 WIB yang diambil pada rentang waktu 05.00-08.00 WIB. 
b) L2 data pengukuran di jam09.00 WIB yang diambil pada rentang waktu 08.00-12.00 WIB.

c) L3 data pengukuran di jam13.00 WIB yang diambil pada rentang waktu 12.00-16.00 WIB.

d) L4 data pengukuran di jam 17.00 WIB yang diambil pada rentang waktu 16.00-22.00 WIB.

e) L5 data pengukuran di jam22.00 WIB yang diambil pada rentang waktu 22.00-23.00 WIB.

f) L6 data pengukuran di jam 23.00 WIB yang diambil pada rentang waktu 23.00-24.00 WIB.

Hasil pengukuran SLM kemudian dihitung dengan rumus sebagai berikut:

$$
\begin{aligned}
& \mathrm{L}_{\mathrm{S}}=10 \log 1 / 16\left\{\mathrm{~T} 1.10^{0.1 . \mathrm{L} 1}+\ldots+\mathrm{T} 4.10^{0.1 . \mathrm{L} 4}\right\} \mathrm{dB}(\mathrm{A}) \ldots(1) \\
& \mathrm{L} \mathrm{M}=10 \log 1 / 2\left\{\mathrm{~T} 5.10^{0.1 . \mathrm{L} 5}+\ldots+\mathrm{T} 7.10^{0.1 . \mathrm{L} 6}\right\} \mathrm{dB}(\mathrm{A}) \ldots(2) \\
& \mathrm{LSM}=10 \log 1 / 18\left\{16.10^{0.1 . \mathrm{LS}}+\ldots+2.10^{0.1(\mathrm{LM}+5)}\right\} \mathrm{dB}(\mathrm{A}) \ldots(3)
\end{aligned}
$$

Keterangan :

- Leq (Equivalent Continuous Noise Level) ialah nilai tertentu kebisingan dari kebisingan tidak stabil Satuannya adalah $\mathrm{dB}(\mathrm{A})$.

- $\quad$ LS = Leq pengukuran siang hari

- $\quad$ LM = Leq pengukura malam hari

- $\quad$ LSM $=$ Leq pengukuran siang dan malam

- $\quad \mathrm{T}=$ Selang waktu pengukuran

Data yang terukur kemudian di kelompokkan sesuai dengan waktu pengukurannya yaitu LS dan LM yang kemudian dihitung dengan menggunakan persamaan (1) untuk LS dan (2) untuk LM. Selanjutnya untuk mengetahui LSM (tingkat bising sinambung pada siang dan malam) maka digunakan persamaan (3).

Nilai yang didapatkan dari perhitungan diatas selanjutnya diolah menggunakan aplikasi Surfer v11.0.642 dengan memasukkan titik-titik koordinat yang didapat menggunakan aplikasi andorid bernama UTM Geo Map. Titik-titik koordinat yang diambil berupa bujur timur dan lintang utara. Aplikasi surfer digunakan untuk memetakan sebaran kebisingan dari hasil pengukuran yang didapatkan, dengan hasil berupa peta kontur kebisingan yang mana penentuan titik-titik tak terukur didapatkan menggunakan metode kriging.

\section{HASIL DAN PEMBAHASAN}

\section{Nilai Kebisingan pada Gang B}

Pengukuran pada Gang B di lakukan sejak jam 06.00 s/d jam 24.00 WIB. Pengambilan data pada jarak pengukuran sejauh 20 meter, B2 40 meter, B3 60 meter, B4 80 meter.

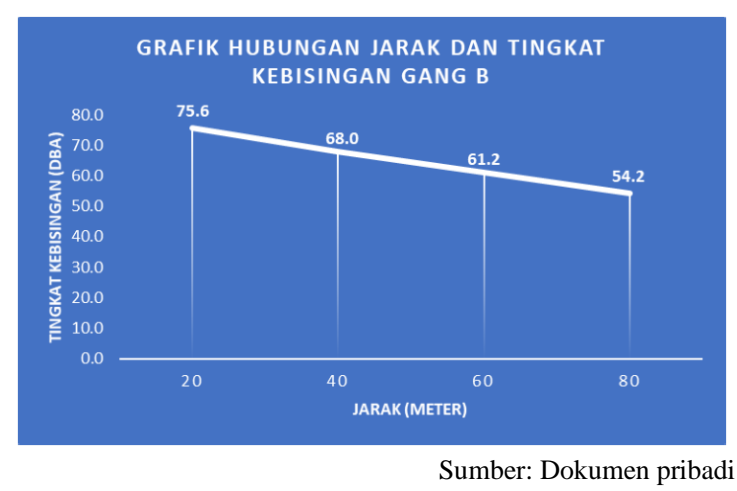

\section{Gambar 4. Grafik Hubungan Jarak dan Tingkat Kebisingan pada Gang B}

Berdasarkan Gambar 4 hasil pengukuran kebisingan LSM pada jarak $20 \mathrm{~m}$ adalah $75,6 \mathrm{dBA}$, jarak 40m yaitu $68,0 \mathrm{dBA}$, jaral $60 \mathrm{~m}$ adalah $61,2 \mathrm{dBA}$, sedangkan pada jarak $80 \mathrm{~m}$ sebesar 54,2 dBA. Hal ini menunjukkan bahwa semakin jauh jarak dari sumber suara (kereta yang melintas) maka tingkat kebisingannya-pun semakin rendah. 


\section{Nilai Kebisingan pada Gang C}

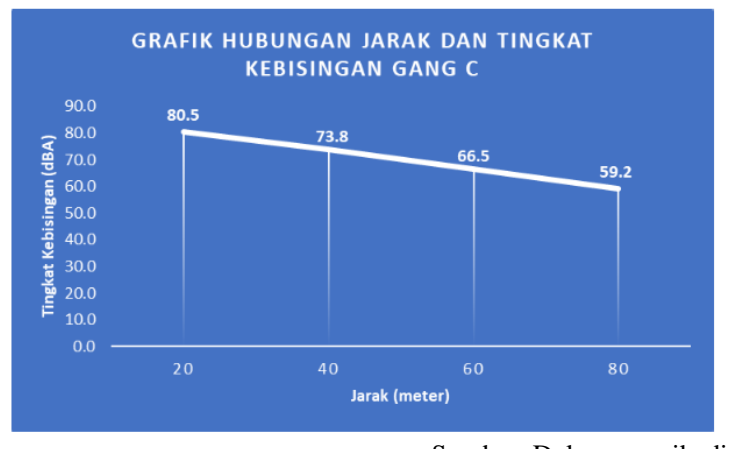

Sumber: Dokumen pribadi

Gambar 5. Grafik Hubungan Jarak dan Tingkat Kebisingan pada Gang C

Berdasarkan Gambar 4 hasil pengukuran kebisingan LSM pada jarak $20 \mathrm{~m}$ adalah $80,5 \mathrm{dBA}$, jarak 40m yaitu 73,8 dBA, jaral $60 \mathrm{~m}$ adalah 66,5 dBA, sedangkan pada jarak $80 \mathrm{~m}$ sebesar 59,2 dBA.

\section{Nilai Kebisingan pada Gang D}

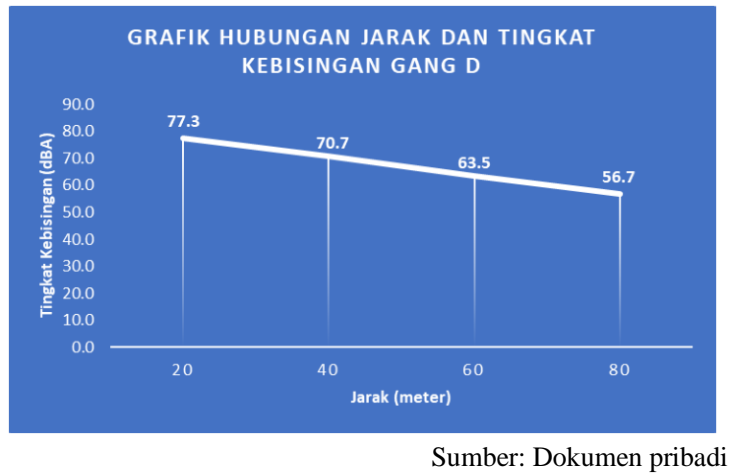

Gambar 6. Grafik Hubungan Jarak dan Tingkat Kebisingan pada Gang D

Hasil pengukuran LSM pada Gang D ditunjukkan pada Gambar 6. Nilai kebisingan pada jarak $20 \mathrm{~m}$ adalah 77,3 dBA, jarak 40m yaitu 70,7 dBA, jaral $60 \mathrm{~m}$ adalah 63,5 dBA, sedangkan pada jarak 80 m sebesar 56,7 dBA.

\section{Analisis Kebisingan pada Tiap Gang}

Data hasil pengukuran tingkat kebisingan pada penelitian ini Gang B di ambil pada Jl. Tebet Timur Dalam VIII B, Gang C diambil pada Jl. Tebet Timur Dalam VIII C, dan Gang D diambil pada Jl. Tebet
Timur Dalam VIII D. Masing-masing Gang memiliki jarak \pm 33 meter dengan kondisi penghalang pada pinggir rel kereta yang berbeda-beda. Pada Gang B terdapat tiga pohon besar (satu pohon kelapa dan dua pohon flamboyan kuning), sedangkan pada Gang C tidak terdapat penghalang, dan pada Gang D terdapat tembok beton yang menutupi. Dari masing-masing Gang ditentukan 4 titik pengukuran untuk memudahkan mendapatkan data sebaran kebisingan pada setiap Gang, dan setiap titik pengukuran dilakukan pada jam 06.00 sampai dengan jam 24.00 WIB .

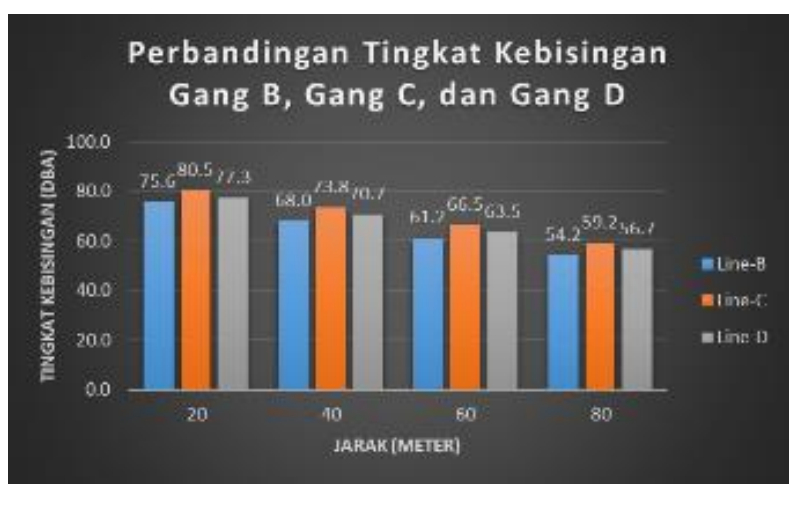

Sumber: Dokumen pribadi

Gambar 7. Grafik Perbandingan Tingkat Kebisingan pada Gang-B, Gang-C, dan Gang-D

Grafik perbandingan tingkat kebisingan dengan hasil pengukuran pada Gang B, Gang C, dan Gang D diatas menunjukkan adanya perbedaan nilai LSM pada setiap set point pengukuran. Bila dibandingkan maka nilai Lsm yang tertinggi terdapat pada Gang C yaitu sebesar 59,2 dBA dengan jarak 80 meter dari sumber kebisingan (kereta yang melintas), dan nilai LSM yang terendah terdapat pada Gang B yaitu 54,2 dBA pada jarak 80 meter dengan selisih 5 dBA. Hal ini terjadi dikarenakan adanya penghalang pohon dengan lingkar batang masing-masing, pohon kelapa $1,21 \mathrm{~m}$; pohon flamboyan kuning A 1,40 m; dan pohon flamboyan kuning $\mathrm{B} 1,86 \mathrm{~m}$; yang terdapat pada Gang B yang membatasi antara perumahan dan rel kereta. Adanya pohon pada Gang B tersebut mereduksi 
tingkat kebisingan pada Gang B sebesar 5 dBA. Sedangkat pada Gang C tidak terdapat penghalang apapun, sehingga tidak ada apapun yang mereduksi kebisingan yang dihasilkan oleh kereta yang melintas yang menyebabkan nilai tingkat kebisingan pada Gang $\mathrm{C}$ memiliki selisih yang paling tinggi diantara ke tiga Gang tempat penelitian dilakukan. Adapun pada Gang D terdapat tembok penghalang setinggi $2,5 \mathrm{~m}$ dengan ketebalan $0,03 \mathrm{~m}$ yang berada $5 \mathrm{~m}$ dari rel kereta. Adapun selisih nilai tingkat kebisingan yang didapat antara Gang B dengan Gang C sebesar 5 dBA, Gang C dengan Gang D sebesar 2,5 dBA, dan selisih nilai tingkat kebisingan antara Gang B dan Gang D sebesar 2,5 dBA.

Upaya untuk mereduksi tingkat kebisingan diantaranya penanaman pohon dan pembangunan tembok beton. Pohon dan beton masing-masing dapat mereduksi kebisingan sebesar 3,4 - 8 dBA untuk pohon dengan kerapatan daun paling minim, dan 15 - 20 dBA untuk tembok beton dengan miniman tinggi $2,5 \mathrm{~m}$, tebal $0,05 \mathrm{~m}$, serta panjang minimal $100 \mathrm{~m}$ [6]. Setidaknya dibutuhkan $30 \mathrm{~m}$ dari sumber bising yang dihalangi dengan pepohonan untuk mengurangi kebisingan minimal 5 dBA dengan tingkat kerimbunan daun paling minim. Pohon dengan diameter batang minimal 0,2 $\mathrm{m}$ dapat memantulkan, membelokkan, serta menghamburkan gelombang bunyi,dan meredam kebisingan hingga 8,1 dBA [7].

Lebar batang, kedalaman akar, dan tinggi pohon berpengaruh dalam peredaman kebisingan dan dapat meredam kebisingan 3-10 dBA untuk pohon dengan diameter $>0,2 \mathrm{~m}$ dan jarak ukur 10-25 $\mathrm{m}$ dari sumber kebisingan (jalan raya). Hal ini dijelaskan karena kedalaman akar, batang pohon, cabang, dan daun memiliki karakteristik untuk menyerap, ataupun menghamburkan resonansi [8].
Pagar beton di pinggir jalan dapat mereduksi kebisingan yang diterima di area perumahan hingga 9,02 dBA dengan jarak $2 \mathrm{~m}$ dari tembok beton pembatas [9]. Tembok beton sebagai upaya mereduksi kebisingan dapat mereduksi kebisingan 14 dBA dengan jarak $8,5 \mathrm{~m}$, sedangkan pada jarak terjauh yaitu $50 \mathrm{~m}$ mereduksi sebesar 3,3 dBA. Hal ini menjelaskan bahwa tembok beton dengan tinggi $4 \mathrm{~m}$ baik digunakan untuk mereduksi kebisingan dengan jarak tidak lebih dari $10 \mathrm{~m}$ dari tembok penghalang.

Dalam penelitian ini didapatkan bahwasanya pohon mereduksi kebisingan lebih tinggi bila dibandingkan dengan pembatas tembok [10], dikarenakan ketiga pohon pembatas yang memiliki diameter 0,4 - 0,6 $\mathrm{m}$ diasumsikan dapat menyerap ataupun menghamburkan kebisingan yang kemudian dihamburkan oleh temboktembok rumah di kiri dan kanan tempat penelitian berlangsung (gang) sehingga semakin melemahkan gelombang bunyi yang diterima pada titik pengekuran. Sedangkan tembok pembatas dengan tinggi 2,5 meter dan tebal 0,03 m pada Gang D mereduksi lebih kecil bila dibandingkan dengan pohon pada Gang B yang dikarenakan tinggi kereta yang melintas lebih tinggi $0,5 \mathrm{~m}$ dibandingkan dengan tinggi penghalang (tembok). Dengan demikian separuh dari sumber suara tidak terhalang oleh apapun pada Gang D dan menyebabkan tidak optimalnya fungsi tembok sebagai pereduksi tingkat kebisingan pada daerah tersebut, dan juga diasumsikan karena ketebalan tembok hanya $0,03 \mathrm{~m}$.

\section{Peta Kontur Distribusi Tingkat Kebisingan}

Pemetaan sebaran kebisingan menggunakan aplikasi Surfer dan menggunakan metode kriging untuk mendapatkan nilai tak terukur menggunakan nilai terukur seperti yang 
telah dijelaskan sebelumnya. Data LSM pada setiap titik ukur dalam setiap gang dimasukkan beserta koordinat yang diperoleh dari aplikasi UTM Geo Map. Data nilai tingkat kebisingan beserta koordinat yang telah dimasukkan kemudian diproses oleh aplikasi Surfer dengan beberapa metode yang sudah tersedia di dalamnya.

Berikut hasil pemetaan kebisingan menggunakan aplikasi surfer.

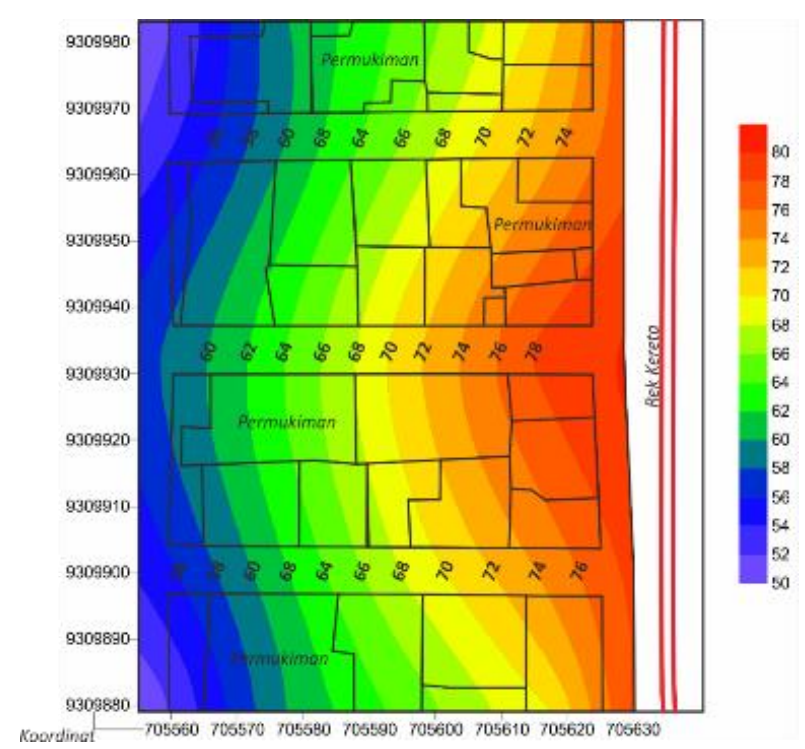

Sumber: Dokumen pribadi

\section{Gambar 9. Peta Kontur Sebaran Kebisingan}

Dikethui bahwa pengaruh pohon dan tembok penghalang pada Gang B dan Gang D memiliki nilai sebaran tingkat kebisingan (LSM) yang sangat berpengaruh dalam penentuan jarak aman untuk pembangunan rumah disekitar rel kereta dengan NAB 55 dBA.

\section{SIMPULAN}

Pada penelitian diperoleh hasil LSM tertinggi pada jarak 20 meter dari sumber kebisingan pada Gang C sebesar 80,5 dBA, dan data hasil LSM terendah pada jarak 80 meter dari sumber kebisingan pada Gang B sebesar 54,2 dBA. Dengan demikian jarak aman yang direkomendasikan untuk mendirikan permukiman adalah diatas 80 meter dengan tingkat kebisingan dibawah 55 dBA dengan catatan memberi penghalang berupa pohon atau tembok beton yang membatasi pinggir rel kereta pada jarak minimal sejauh lima meter dengan daerah permukiman warga.

\section{DAFTAR PUSTAKA}

[1] Egan, David M. (1998). ArchitecturalAcoustic. Mc Graw Hill: New York.

[2] Rusli, Mustar. (2008). Pengaruh Kebisingan dan Getaran Terhadap perubahan Tekanan Darah Masyarakat yang Tinggal di Pinggir Rel Kereta Api Lingkungan XIV Kelurahan Tegal Sari Kecamatan Medan Denai Tahun 2008. Tesis: Program Manajemen Kesehatan Lingkungan Industri pada Sekolah Pascasarjana. Universitas Sumatera Utara

[3] Suroto W. Dampak Kebisingan Lalu Lintas Terhadap Permukiman Kota (Kasus Kota Surakarta). Journal of Rural and Development :, vol. 1, no. 1, pp. 55-62, Februari 2010.

[4] Kementerian Negara Lingkungan Hidup. (1996). Keputusan Menteri Negara Lingkungan Hidup. Kep 48/MENLH/11/1996 tentang Baku Tingkat Kebisingan. Meteri Negara Lingkungan Hidup: Jakarta

[5] SNI. (2009). Metode Pengukuran Tingkat Kebisingan di Tempat Kerja. SNI 7231: 2009. Jakarta: Badan Standarisasi Nasional

[6] Kementerian Negara Pekerjaan Umum. (2005). Mitigasi Dampak Kebisingan Akibat Lalu Lintas Jalan. Departemen Pekerjaan Umum. Jakarta

[7] Renterghem, T.V. (2000). Guidelines For Optimizing Road Traffic Noise Shielding By Non-Deep Tree Belts. Ghent University: Belgia 
[8] Fang, C.F, \& Ling, D.L. (2005).

[10] Wardika I.K., Suparsa I.G.P., Guidance for Noise Reduction Priyantha W.D.M., Jurnal Ilmiah Provided by Tree Belts. National Taiwan University: Taiwan

[9] Umiati Sri. (2012) Pengaruh Pagar Tembok Terhadap Kebisingan. Jurnal Rekayasa Sipil. Universitas Andalas: Sumatera Barat Vol 8 No.1, Februari 2012 Elektronik Infrastruktur Teknik Sipil: Analisis Kebisingan Lalu Lintas Pada Ruas Jalan Arteri (Studi Kasus Jalan Prof. Dr. IB. Mantra Pada KM 15s/d KM 16) vol. 1, no. 1, pp. 1-8, Desember 2012 